\title{
The Effect of Entrepreneurial Networking and Entrepreneurial Marketing on MSMEs Performance through Product Innovation (Case Study in East Java)
}

\author{
Eva Mufidah ${ }^{1}$, Ascosenda Ika Rizqi ${ }^{1}$, Anis Eliyana ${ }^{2}$, Indrianawati Usman ${ }^{2}$, A.Ratna \\ Pudyaningsih $^{1}$, Vita Fibriyani ${ }^{1}$ \\ ${ }^{1}$ Universitas Merdeka Pasuruan \\ ${ }^{2}$ Universitas Airlangga Surabaya
}

\begin{abstract}
The growth of micro businesses in Indonesia, especially in the City of Pasuruan is very rapid. In Pasuruan City in 2017 it was explained that there were approximately 30 thousand micro businesses with various sectors. Micro businesses are not only required to have good entrepreneurial networking and marketing, but also must be able to compete with other micro businesses. This study aims to determine how the influence of entrepreneurial networking and marketing on the performance of micro businesses through product innovation. The population of the furniture business is \pm 675 MSMEs, the sample taken is 135 MSMEs entrepreneurs. By using SEM analysis techniques, the results show that entrepreneurial networking and entrepreneurial marketing affect the performance of MSMEs but for product innovation it does not have an impact on the performance of MSMEs so that this needs to be a concern for the government of Pasuruan City for progress for MSMEs entrepreneurs.
\end{abstract}

Keywords: MSMEs, Entrepreneurial Networking, Entrepreunerial Marketing, Inovation, SEM

\section{Introduction}

Building an entrepreneurial MSMEs sector is very potential as a foundation for increasing national economic growth in the era of free trade. Isnaeni (2009) states that the informal sector is a small-scale business that produces and distributes goods and services with the main goal of creating employment and income for oneself, where in business it is severely limited by capital and skills. Likewise, in the face of competition in an increasingly high and complex industrial world, resources are needed that have entrepreneurial abilities.

The existence of entrepreneurial networking and entrepreneurial marketing is expected to bring the growth of MSMEs. Both of these variables have been implemented by business actors quite well where the ability of the two variables is shown in market growth.

Performance is a variable that can be used to measure the achievement of a business. Ismawanti (2008) states that marketing performance is an important element of company performance in general because a company's performance can be seen from its marketing performance.

Pasuruan City has approximately 30 thousand MSMEs spread across various sectors. As 
we know, that Pasuruan City is known for its furniture products, where we find many in some regions, such as Bukir. The furniture industry is able to contribute to the economy of the community as well as the regional economy. For this reason, there needs to be support from academics and government to improve the regional economy through MSMEs. This has encouraged researchers to study more closely related to the performance of MSMEs, especially furniture. What factors can improve MSME performance in this millennial era and how to deal with MEA.

\section{Research Methods}

This research was conducted to MSMEs engaged in furniture which are spread in Gadingrejo and Purworejo Districts, Pasuruan City. When the study began in Januari - Juli 2019. According to data provided by the Diskoperindag MSMEs actors as many as \pm 675 MSMEs. The sampling technique used was using purposive sampling method. The number of samples used is $20 \%$. Samples of 135 MSMEs were taken. The data used in this study include primary data and secondary data, where primary data is related to the results of interviews with respondents and secondary data related to the number of MSMEs from the Diskoperindag. The analysis used is to use the Structural Equation Model (SEM) using AMOS SEM software application according to Ghozali (2015) is a multivariate technical analysis that allows researchers to test the analysis directly and indirectly between complex variables both recursive and non recursive to obtain a comprehensive picture a model.

The Entrepreneurial Networking variable according to Premaratne (2002) was assessed using three indicators namely; 1). Determinant (decisive thing). Determinant in small scale businesses namely social, communication, business and morals, 2). Link (link). The link between relationships is formal-informal, voluntary-compulsory (voluntary-mandatory) and directly-indirectly. 3). Objectives (goals). The objectives of the network depend on the business being carried out.

For Entrepreneurial Marketing variables are examined with four indicators which include concepts, strategies, methods and market intelligence according to Stokes (2000).

The product innovation variable according to Hurley and Hult (1998) explains that product innovation is the impact of rapid technological changes and high product variations will determine competitive advantage. Rapid technological progress and high levels of competition require every effort to continuously innovate products that will ultimately increase the competitive advantage in the business.

The MSMEs Performance Variable is assessed with four indicators, namely sales growth, customer growth, profit growth, and working capital growth (Wahyuningsih, 2017). 


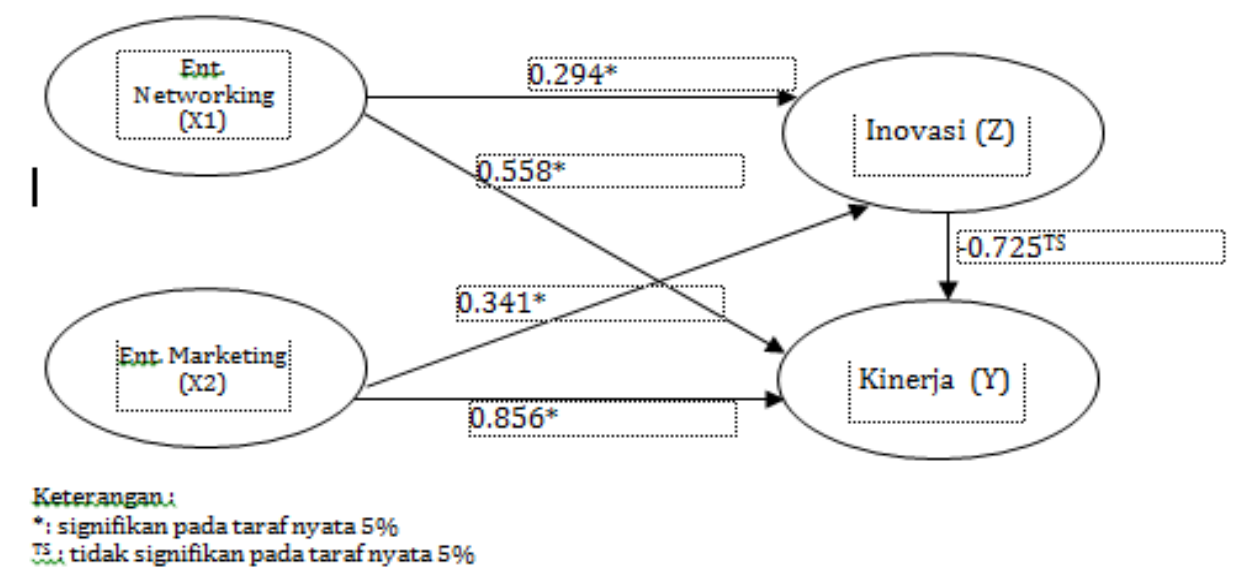

Sumber: Data primer yang dioleh, 2019

Figure 1. Causal Relations Between Variables

Based on the framework in the picture above, the research hypothesis is formulated as follows:

H1: Effect of Entrepreneurial Networking on the performance of MSMEs

H2: Effect of Entrepreneurial Marketing on MSMEs performance

H3: The Effect of Entrepreneurial Networking on the performance of MSMEs through product innovation

H4: The Effect of Entrepreneurial Networking on the performance of MSMEs through product innovation

H5: Effect of product innovation on MSMEs performance

\section{Result and Discusion}

Before data retrieval is done using a questionnaire, testing the questionnaire includes a validity test and a reliability test. Instrument testing was carried out on 38 respondents. From the results of testing the validity and reliability, the variable entrepreneur networking, entrepreneur marketing and product innovation are declared valid because the significance value on the Pearson correlation coefficient is smaller than the real level of 5\%. To test the reliability of the entepreneurial networking variable, entepreneurial marketing and product innovation are stated to be reliable because the Cronbach Alpha value is greater than 0.6.

Before testing the hypothesis, in a linear regression analysis, assumptions are tested, one of which is the multicollinearity assumption. Multicollinearity testing aims to test whether the regression model found an independent correlation between variables. Independent variables as much as 3 were analyzed by their colinearity using two criteria, namely Variance Inflation Factor (VIF) and tolerance value. A variable is said to be free of multicollinearity if the VIF value is less than 10 and the tolerance value is greater than 0.10 . The results of muliticollinearity testing are presented in Table 1, it appears that there is no collinearity 
between independent variables involved in the study. This is evidenced by the VIF value and tolerance value of each independent variable smaller than 10 and greater than 0.10 .

Table 1. Multicollinearity Test Results

\begin{tabular}{llll}
\hline Variabel Independen & Nilai VIF & $\begin{array}{l}\text { Nilai } \\
\text { Tolerance }\end{array}$ & Keterangan \\
\hline Ent. Networking & 3.848 & 0.260 & Tidak Terjadi \\
Ent. Marketing & 3.980 & 0.251 & Kolinearitas \\
Inovasi & 1.919 & 0.521 & antarvariabel \\
\hline
\end{tabular}

\section{Descriptive Analysis}

This research was conducted by sampling, the sampling technique used in this study was purposive sampling where the number of samples taken as much as $20 \%$ of the umkm of food and drinks that are still active in the City of Pasuruan is a number of \pm 675 units. The results of descriptive analysis of the variables involved in this study are explained in the following table:

Table 2. Descriptive Variable Analysis

\begin{tabular}{lccc}
\hline Indicator & Mean & Median & Deviasi \\
\hline X1 Ent Networking & & & \\
X1.1 Determinant & 4.04 & 4.00 & 0.937 \\
X2.1.Link & 4.02 & 4.00 & 0.910 \\
X2.1.Objective & 3.96 & 4.00 & 0.976 \\
X2 Ent Marketing & & & \\
X2.1 Concept & 4.02 & 4.00 & 0.926 \\
X2.2 Strategy & 4.00 & 4.00 & 0.946 \\
X2.3 Method & 3.99 & 4.00 & 1.007 \\
X2.4 Market Intelligence & 4.00 & 4.00 & 1.058 \\
Z Inovation & & & \\
Z1.1 & 4.16 & 4.00 & 0.812 \\
Z1.2 & 4.20 & 4.00 & 0.721 \\
Z1.3 & 4.29 & 4.00 & 0.679 \\
Y Performance & & & \\
Y1.1 & 4.00 & 4.00 & 0.962 \\
Y1.2 & 4.07 & 4.00 & 0.986 \\
Y1.3 & 4.04 & 4.00 & 0.984 \\
Y1.4 & 4.01 & 4.00 & 0.938 \\
\hline
\end{tabular}

Entrepreneurial Networking is measured by 3 things: determinants, links and objectives. Based on descriptive analysis, the mean and median values of 4 for the three indicators mean that most MSMEs in the city of Pasuruan expressed their agreement regarding the need to build networks to improve MSMEs performance in Pasuruan City.

Entrepreneurial marketing is measured from 4 things namely concepts, strategies, methods and intelligence. Based on descriptive analysis, the mean and median values of 4 for all indicators mean that most MSMEs in Pasuruan city agreed that they are related to the importance of marketing concepts, strategies and techniques in running a business to improve MSMEs performance in Pasuruan City.

Innovation is measured from 3 things namely Z1.1, Z1.2 and Z1.3. Based on descriptive 
analysis, the mean and median values of 4 for the three indicators mean that most MSMEs in the city of Pasuruan expressed their agreement regarding the need to innovate business products on the road or from sales techniques to improve the performance of MSMEs in Pasuruan City.

Performance is measured from 4 things namely Y1.1, Y1.2, Y1.3 and Y1.4. Based on descriptive analysis, the mean and median values of 4 for the four indicators mean that most of the MSMEs in the city of Pasuruan stated agreed related to things that support the realization of a good umkm performance.

In modeling Structural Equation Modeling (SEM) begins with a model feasibility test using several criteria. Following are the results of the calculation of goodness of fit indices from the proposed structural model.

Table 3. GIF results from structural models

\begin{tabular}{llll}
\hline Criteria & Cut-off Score & The calculation results & Information \\
\hline Chi-square & Expected to be small & 47.500 & \\
Probability & $\geq 0.05$ & 0.651 & \\
Cmin/df & $\leq 2.00$ & 0.913 & Decent Model \\
GFI & $\geq 0.90$ & 0.954 & \\
RMSEA & $\leq 0.08$ & 0.000 & \\
\hline
\end{tabular}

Based on the calculation results in Table 3 it appears that all the criteria can be met so that it can be said that the proposed structural model is appropriate or appropriate. For further testing the hypothesis by looking at the loading factor and the significance value of the connected variables.

Table 4. Loading Factors and Significance Value of Causal Relationships between networking, marketing, innovation and the performance of Micro and Small and Medium Enterprises in Pasuruan City

\begin{tabular}{llll}
\hline \multicolumn{1}{c}{ Variable } & \multicolumn{1}{c}{ Loading Factor } & Significance Value & \multicolumn{1}{c}{ Information } \\
\hline Networking $\rightarrow$ Inovation & 0.294 & 0.000 & Significant \\
Marketing $\rightarrow$ Inovation & 0.341 & 0.000 & Significant \\
Networking $\rightarrow$ Performnce & 0.558 & 0.011 & Significant \\
Marketing $\rightarrow$ Performnce & 0,856 & 0.000 & Significant \\
Inovation $\rightarrow$ Performnce & -0.725 & 0.276 & No Significant \\
\hline
\end{tabular}

Entrepreneurial networking has a significant and positive influence on MSME innovation in Pasuruan City. This is as the result of research from Awais and Manzoor Arain (2011). In addition, entrepreneurial marketing also has a significant and positive influence on MSMEs performance in Pasuruan City, where the results of this study are in line with Arfanly's (2016) research. In the millennial era, where demands for creativity and product innovation are needed by each MSMEs owner for sustainability. One of the things that influences product innovation is related to marketing. Based on the results of this study, entrepreneurial marketing has a significant and positive influence on MSMEs innovation in Pasuruan City, where these results support Arfanly's research (2011). However, MSMEs performance in Pasuruan City is only influenced by entrepreneurial netwoking and entrepreneurial marketing, while innovation has less impact which is significant to the performance of MSMEs in Pasuruan City. 


\section{Conclusion}

a) Based on the results of the analysis that has been done, several conclusions can be drawn as follows:

b) Entrepreneurial networking has a significant and positive influence on the innovation of food and beverage MSMEs in Pasuruan City with a contribution of $29.4 \%$

c) Entrepreneurial marketing has a significant and positive influence on the innovation of food and beverage MSME in Pasuruan City with a contribution of $34.1 \%$

d) Entrepreneurial networking has a significant and positive influence on the performance of food and beverage MSMEs in Pasuruan City with a contribution of 55.8\%

e) Entrepreneurial marketing has a significant and positive influence on the performance of food and beverage MSMEs in Pasuruan City with a contribution of $85.6 \%$

f) Innovation has no significant effect on the performance of furniture ummas in Pasuruan City

\section{Acknowledgment}

We would like to thank Allah SWT, Our Parents, Family, Universitas Merdeka Pasuruan, Universitas Airlangga Surabaya

\section{References}

[1] Arfanly, Bibi, et al. 2016. Peran Entrepreneurial Marketing dalam Peningkatan Kinerja Pemasaran pada Industri Rumahan Kabupaten Kendal, Jawa Tengah. Manajemen IKM, Vol. 11, No. 2.

[2] Awais Ahmad Tipu \& Manzoor Arain, F.(2011). Managing succes factors in entrepreneurial ventures: a behavioral approach. International Journal of Entrepreneurial Behavior \& research, 17(5), 534-560.

[3] Ghozali, I.2015.Partial Least Squaeres Konsep Teknik dan Aplikasi Menggunakan Program Smart PLS 3.0. Semarang. (ID): Badan penerbit Universitas Diponegoro

[4] Hacioglua, Gungor., 2012, The Effect of Entrepreneurial Marketing on Firms Innovative Performance in Turkish SMEs, Procedia - Social and Behavioral Sciences. 58, pp. 871 - 878

[5] Hamali, Sambudi., 2013, Increasing Innovation Through Entrepreneurial Marketing and The Impact on Marketing Performance of Garment SMEs in West Java, Proceeding — Seminar Nasional Sustainable Competitive Advantages - 3 Fakultas Ekonomi Universitas Jenderal Soedirman, pp. 1-13.

[6] Hurley, R.\& Hult, G.T. 1998. Innovation, Market Orientation and Organizational Learning: An Integration and Empirical Exemination. Journal of Marketing, 62(3):42-54.

[7] Ismawanti, E. 2008. Analisis Faktor-Faktor yang Mempengaruhi Kinerja Pemasaran dengan Faktor Lingkungan Sebagai Peubah Moderat. [Thesis]. Semarang: Program Studi Magister Manajemen, Sekolah Pascasarjana Universitas Diponegoro.

[8] Isnaeni. 2009. "Pengaruh Perilaku Kewirausahaan, Segmentasi Pasar dan Modal Usaha Terhadap Laba Usaha Industri Kerajinan Meubel Di Sambi Boyolali”. SkripsiTidak Dipublikasikan. Universitas Muhammadiyah Surakarta. Knight, Gary. 2000. "Entrepreneurship and marketing strategy: The SME under globalization". Journal of international marketing. Vol. 2. Pp. 12-21.

[9] Kotler, 2008, Manajemen Pemasaran, Edisi Kesebelas, Jilid I, Penerbit: PT. Indeks Kelompok Media, Jakarta. 
[10] Moghli, Azzam Abou and Muala, Ayyed. 2012. "Impact of Entrepreneursjip Networks In The Success of Business Ongoing Stage In Jordanian Manufacturing Companies". American Academic \& Scholarly Research Journal. Vol. 4. No. 2. Pp. 76-91.

[11] Premaratne, S.P. (2002), Entepreneurial network and small business development: The case of small enteprises in Sri Lanka, Eidhoven: Technische Universite Eindhoven.

[12] Septiani at al, 2013. Pengaruh Entrepreneurial Marketing dan Kebijakan Pemerintah terhadap Daya Saing Industri Alas Kaki di Bogor, Jurnal Manajemen dan Oraganisasi, Volume IV Nomor 2 hal 91-111.

[13] Stokes, D. 2000. Putting Entrepreneurship Into Marketing. Journal of Research in Marketing \& Entrepreneurship: 2 (1)

[14] Venkatraman, 2009, Strategic Orientation of Business Entreprises the Construct, Dimensionality and Measurement. Management Science. Vol. 35.No. 8. pp-942-962. 